\title{
Transport and fate of hexachlorocyclohexanes in the oceanic air and surface seawater
}

\author{
Z. Xie ${ }^{1}$, B. P. Koch ${ }^{2,3}$, A. Möller ${ }^{1}$, R. Sturm ${ }^{1}$, and R. Ebinghaus ${ }^{1}$ \\ ${ }^{1}$ Helmholtz-Zentrum Geesthacht, Centre for Materials and Coastal Research GmbH, Institute of Coastal Research, \\ Max-Planck Street 1, 21502 Geesthacht, Germany \\ ${ }^{2}$ Alfred Wegener Institute for Polar and Marine Research, Bremerhaven, Germany \\ ${ }^{3}$ University of Applied Sciences, Bremerhaven, Germany
}

Received: 24 May 2011 - Published in Biogeosciences Discuss.: 9 June 2011

Revised: 8 September 2011 - Accepted: 12 September 2011 - Published: 19 September 2011

\begin{abstract}
Hexachlorocyclohexanes (HCHs) are ubiquitous organic pollutants derived from pesticide application. They are subject to long-range transport, persistent in the environment, and capable of accumulation in biota. Shipboard measurements of $\mathrm{HCH}$ isomers $(\alpha-, \gamma-$ and $\beta-\mathrm{HCH})$ in surface seawater and boundary layer atmospheric samples were conducted in the Atlantic and the Southern Ocean in October to December of 2008. $\Sigma$ HCHs concentrations (the sum of $\alpha-, \gamma$ - and $\beta-\mathrm{HCH})$ in the lower atmosphere ranged from 12 to $37 \mathrm{pg} \mathrm{m}^{-3}$ (mean: $27 \pm 11 \mathrm{pg} \mathrm{m}^{-3}$ ) in the Northern Hemisphere $(\mathrm{NH})$, and from 1.5 to $4.0 \mathrm{pg} \mathrm{m}^{-3}$ (mean: $2.8 \pm 1.1 \mathrm{pg} \mathrm{m}^{-3}$ ) in the Southern Hemisphere $(\mathrm{SH})$, respectively. Water concentrations were: $\alpha-\mathrm{HCH} 0.33-47 \mathrm{pg} \mathrm{l}^{-1}$, $\gamma$-HCH $0.02-33 \mathrm{pg}^{-1}$ and $\beta$-HCH $0.11-9.5 \mathrm{pg} \mathrm{l}^{-1}$. Dissolved $\mathrm{HCH}$ concentrations decreased from the North Atlantic to the Southern Ocean, indicating historical use of HCHs in the NH. Spatial distribution showed increasing concentrations from the equator towards North and South latitudes illustrating the concept of cold trapping in high latitudes and less interhemispheric mixing process. In comparison to concentrations measured in 19871999/2000, gaseous HCHs were slightly lower, while dissolved HCHs decreased by factor of 2-3 orders of magnitude. Air-water exchange gradients suggested net deposition for $\alpha-\mathrm{HCH}$ (mean: $3800 \mathrm{pg} \mathrm{m}^{-2} \mathrm{day}^{-1}$ ) and $\gamma-\mathrm{HCH}$ (mean: $2000 \mathrm{pg} \mathrm{m}^{-2} \mathrm{day}^{-1}$ ), whereas $\beta$-HCH varied between equilibrium (volatilization: $<0-12 \mathrm{pg} \mathrm{m}^{-2} \mathrm{day}^{-1}$ ) and net deposition (range: 6-690 $\mathrm{pg} \mathrm{m}^{-2}$ day $^{-1}$ ). Climate change may significantly accelerate the release of "old" $\mathrm{HCH}$ from continental storage (e.g. soil, vegetation and high mountains)
\end{abstract}

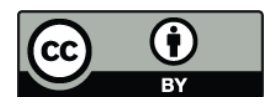

Correspondence to: Z. Xie (zhiyong.xie@ @zg.de) and drive long-range transport from sources to deposition in the open oceans. Biological productivities may interfere with the air-water exchange process as well. Consequently, further investigation is necessary to elucidate the long term trends and the biogeochemical turnover of $\mathrm{HCHs}$ in the oceanic environment.

\section{Introduction}

Hexachlorocyclohexanes (HCHs) are ubiquitous organic pollutants derived from pesticide application. They are subject to long-range transport, persistent in the environment, and capable of accumulation in biota (Nizzetto et al., 2010). $\mathrm{HCH}$ can enter the coast, marine and oceanic environment by a number of processes, once introduced they are subject to biogeochemical cycling, sinks, and bioaccumulation processes. Apart from river discharge and continental runoff, the atmospheric deposition is considered to be the primary and most rapid pathway for persistent organic pollutants to the coast and the marine environment as a result of their hydrophobic and semi-volatile nature (Lohmann et al., 2007). Besides, it has been discussed that re-emission of $\mathrm{HCH}$ from indirect sources such as soils, sediments, vegetation, phytoplankton and "old" concentrations in the ocean, which may interfere the air-water exchange process and governs their circulation and transport in the marine environment (Dachs et al., 2002; Fenner et al., 2004; Jaward et al., 2004; Lohmann et al., 2006).

As one of legacy pesticides, hexachlorocyclohexanes (HCHs) have been extensively studied for their regional and long-range transport via atmosphere, ocean current and exchange among different media (Wu et al., 2010; Bidleman et

Published by Copernicus Publications on behalf of the European Geosciences Union. 


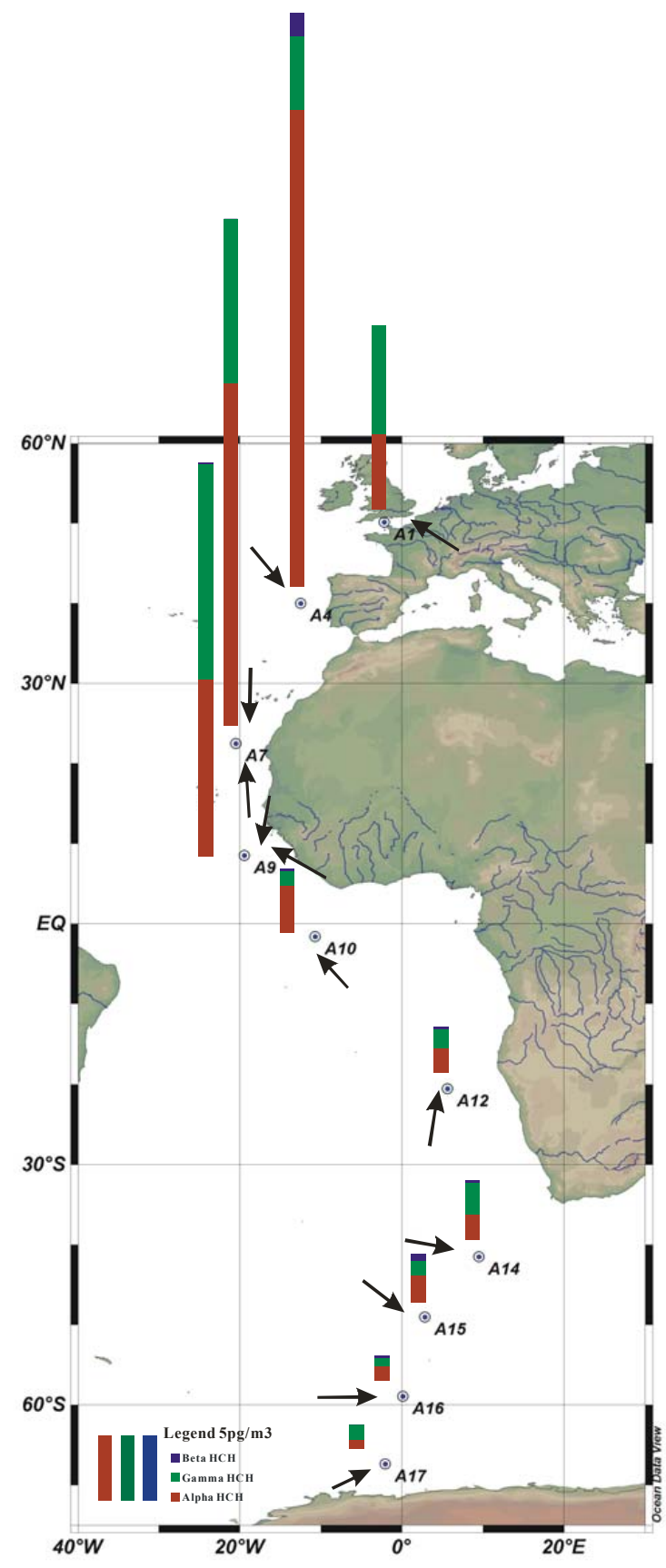

(a)

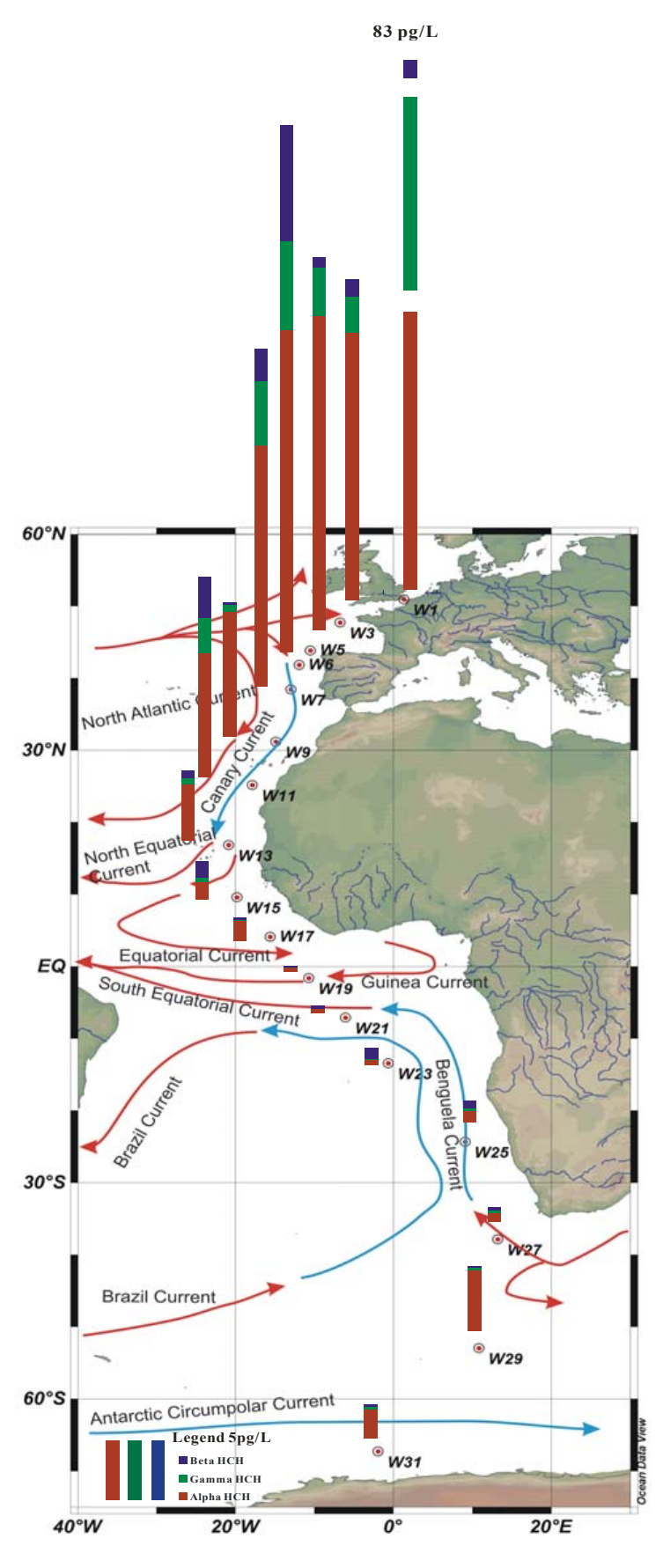

(b)

Fig. 1. (a) Gaseous $\left(\mathrm{pg} \mathrm{m}^{-3}\right.$ ) and (b) dissolved ( $\mathrm{pg}^{-1}$ ) concentrations of $\alpha$-, $\gamma$ - and $\beta$-HCH in the Atlantic and the Southern Ocean. The bars are placed on the average position for each air and water sample.

al., 1992; Schreitmuller and Ballschmiter, 1995; Lakaschus et al., 2002; Jantunen et al., 2004; Shen et al., 2004; Ding et al., 2007; Brown and Wania, 2008; Lohmann et al., 2009; Breivik et al., 1999). Briefly, HCHs have been used mainly in the Northern Hemisphere from 1940s to 2000 with technical mixtures containing $55-80 \% \alpha-\mathrm{HCH}, 5-14 \% \beta-\mathrm{HCH}$ and $8-15 \% \gamma$-HCH (Iwata et al., 1993; Lakaschus et al., 2002). $\gamma$-HCH known as lindane has been used in Europe and North America until end of 2000 (Li and Macdonald, 2005; Weber et al., 2006). Previous studies showed increasing dissolved 
Table 1. Individual concentrations of $\mathrm{HCHs}$ in the atmosphere $\left(\mathrm{pg} \mathrm{m}^{-1}\right)$ in the Atlantic and the Southern Ocean. Concentrations of $\alpha$-HCH in atmospheric particle phase are showed in the blanket, and $\gamma-\mathrm{HCH}$ and $\beta-\mathrm{HCH}$ are below the method detection limits.

\begin{tabular}{|c|c|c|c|c|c|c|c|c|}
\hline Sample & Date & $\begin{array}{r}\text { Latitude } \\
\left({ }^{\circ} \mathrm{N}\right)\end{array}$ & $\begin{array}{r}\text { Longitude } \\
\left({ }^{\circ} \mathrm{E}\right)\end{array}$ & $\begin{array}{r}\text { Volume } \\
\qquad\left(\mathrm{m}^{3}\right)\end{array}$ & $\begin{array}{r}\text { Temp. } \\
\left({ }^{\circ} \mathrm{C}\right)\end{array}$ & $\begin{array}{l}\alpha-\mathrm{HCH} \\
\left(\mathrm{pg} \mathrm{m}^{-3}\right)\end{array}$ & $\begin{array}{l}\gamma-\mathrm{HCH} \\
\left(\mathrm{pg} \mathrm{m}^{-3}\right)\end{array}$ & $\begin{array}{l}\beta-\mathrm{HCH} \\
\left(\mathrm{pg} \mathrm{m}^{-3}\right)\end{array}$ \\
\hline $\operatorname{MDL}\left(\mathrm{pg} \mathrm{m}^{-3}\right)$ & & & & & & 0.030 & 0.010 & 0.10 \\
\hline $\mathrm{A} 1$ & 2-4 Nov 2008 & 50.120 & -2.184 & 687 & 11.5 & $4.8(0.081)$ & 7.0 & 0.01 \\
\hline A4 & 7-9 Nov 2008 & 40.008 & -12.511 & 640 & 16.5 & $31(<0.030)$ & 4.7 & 1.5 \\
\hline A7 & 12-15 Nov 2008 & 22.500 & -20.499 & 1101 & 21.3 & $22(<0.030)$ & 10 & 0.02 \\
\hline A9 & 16-20 Nov 2008 & 8.503 & -19.452 & 968 & 28.6 & $11(0.17)$ & 14 & 0.05 \\
\hline Mean + SD in NH & & & & & & $17 \pm 11$ & $9.0 \pm 4.0$ & $0.40 \pm 0.75$ \\
\hline A10 & 20-23 Nov 2008 & -1.624 & -10.699 & 877 & 25.5 & $3.0(<0.030)$ & 1.0 & 0.09 \\
\hline A12 & 27-29 Nov 2008 & -20.506 & 5.607 & 522 & 18.9 & $1.5(0.25)$ & 1.3 & 0.08 \\
\hline A14 & 6-8 Dec 2008 & -41.492 & 9.476 & 602 & 19.3 & $1.6(<0.030)$ & 2.0 & 0.09 \\
\hline A 15 & 8-10 Dec 2008 & -49.011 & 2.834 & 516 & 11.2 & $1.8(0.28)$ & 0.9 & 0.42 \\
\hline A16 & 10-12 Dec 2008 & -58.910 & 0.131 & 573 & 3.6 & $0.9(<0.030)$ & 0.5 & 0.12 \\
\hline A17 & 12-15 Dec 2008 & -67.354 & -2.064 & 934 & -2.5 & $0.6(<0.030)$ & 0.9 & 0.04 \\
\hline Mean + SD in SH & & & & & & $1.6 \pm 0.84$ & $1.1 \pm 0.52$ & $0.14 \pm 0.14$ \\
\hline
\end{tabular}

concentrations of $\alpha-\mathrm{HCH}$ with increasing latitude, which might support the theory of cold condensation $\mathrm{HCHs}$ in Polar Regions (Lakaschus et al., 2002; Lohmann et al., 2009). As a consequence of declining atmospheric concentrations, the air-water change of $\alpha-\mathrm{HCH}$ was expected changing from net deposition to volatilization, and the oceans will subsequently turn into sources (Jantunen and Bidleman, 1995). Along the Atlantic, in 1999/2000, air-sea exchange of $\alpha$ and $\gamma-\mathrm{HCH}$ reached an equilibrium in the North Atlantic, whereas the surface waters of the tropical and southern Atlantic were strongly undersaturated with $\gamma-\mathrm{HCH}$ (Lakaschus et al., 2002). Due to the variability of climate and different intrinsic physical-chemical properties of organo-chlorine pesticides, it is necessary to further investigate the state of $\mathrm{HCH}$ in the oceanic environment.

In this study, we analyzed marine boundary layer air and surface water samples in the Atlantic transect and the Southern Ocean for HCHs. The objectives of this study are (1) to update the levels of $\mathrm{HCHs}$ in the atmosphere and the surface seawater, (2) to estimate the air-sea gas exchange directions and fluxes of $\mathrm{HCHs}$, and (3) to evaluate the temporal and latitudinal variability of dissolved HCHs.

\section{Materials and methods}

\subsection{Sampling protocol}

The sampling of air (Fig. 1a) and seawater (Fig. 1b) has been described in Xie et al. (2011). Briefly, seawater and air samples were collected onboard the R/V Polarstern in the Atlantic and Southern Ocean $\left(51^{\circ} \mathrm{N}-67^{\circ} \mathrm{S}\right)$ in October to De- cember 2008. Sampling locations, dates and general sampling conditions were recorded aboard from PODAS (Polarstern Data System) and are summarized in Tables 1 and 2. Seawater samples were collected from the ship's intake system located in the keel (depth: $11 \mathrm{~m}$ ) using a combination of PAD-2 resins (Polystyrene-DVB-copolymer resin, SERVA $\mathrm{GmbH}$, Heidelberg, Germany) and glass fibre filters (GFF: pore size, $0.7 \mu \mathrm{m}$ ). Air samples were collected using GFF filters combined with a glass column packed with PUF/PAD2 at the upper deck (Altitude: $20 \mathrm{~m}$ ). Water and air samples were stored at $4{ }^{\circ} \mathrm{C}$ and $-20^{\circ} \mathrm{C}$, respectively.

\subsection{Chemicals}

All solvents (methanol, acetone, dichloromethane and $n$ hexane) were residue analysis grade and additionally distilled in a full glass unit prior to use. Analytical standards of $\mathrm{HCHs}$ and deuterated $\alpha-\mathrm{HCH}(\mathrm{d} 6-\mathrm{HCH})$ were purchased from Dr. Ehrenstorfer GmbH (Augsburg, Germany), and ${ }^{13} \mathrm{C}$-HCB was obtained from Cambridge Isotope Laboratories.

\subsection{Extraction, clean-up and analysis}

Extraction, clean-up and analysis of the samples were done based on our previously published method (Xie et al., 2011). Briefly, samples were spiked with the surrogate standard d6$\mathrm{HCH}$ prior to extraction, then Soxhlet extracted and purified on $10 \%$ water deactivated silica column. Analysis was done by a GC/MS-system (6890 GC/5975 MSD) in electron capture negative chemical ionization mode (ECNCI). The $\mathrm{m} / \mathrm{z}$ values monitored for quantification and quality control are 
Table 2. Individual concentrations of HCHs in surface seawater $\left(\mathrm{pg}^{-1}\right)$ in the Atlantic and the Southern Ocean.

\begin{tabular}{|c|c|c|c|c|c|c|c|c|c|}
\hline Sample & Date & $\begin{array}{r}\text { Latitude } \\
\left({ }^{\circ} \mathrm{N}\right)\end{array}$ & $\begin{array}{r}\text { Longitude } \\
\left({ }^{\circ} \mathrm{E}\right)\end{array}$ & $\begin{array}{r}\text { Volume } \\
\text { (1) }\end{array}$ & $\begin{array}{r}\text { Temp. } \\
\left({ }^{\circ} \mathrm{C}\right)\end{array}$ & $\begin{array}{c}\text { Salinity } \\
\text { (PSU) }\end{array}$ & $\begin{array}{l}\alpha-\mathrm{HCH} \\
\left(\operatorname{pg~l}^{-1}\right)\end{array}$ & $\begin{array}{l}\gamma-\mathrm{HCH} \\
\left(\mathrm{pg} \mathrm{l}^{-1}\right)\end{array}$ & $\begin{array}{l}\beta-\mathrm{HCH} \\
\left(\mathrm{pg} \mathrm{l}^{-1}\right)\end{array}$ \\
\hline $\operatorname{MDL}\left(\mathrm{pg} \mathrm{l}^{-1}\right)$ & & & & & & & 0.020 & 0.060 & 0.010 \\
\hline W1 & 2 Nov 2008 & 50.923 & 1.311 & 409 & 13.8 & 35.1 & 47 & 33 & 2.7 \\
\hline W3 & 4 Nov 2008 & 47.723 & -6.758 & 1000 & 12.4 & 35.4 & 22 & 2.9 & 1.4 \\
\hline W5 & 6 Nov 2008 & 43.854 & -10.516 & 1073 & 15.4 & 35.7 & 26 & 4.0 & 0.78 \\
\hline W6 & 7 Nov 2008 & 41.855 & -11.946 & 1088 & 15.9 & 35.9 & 26 & 7.2 & 9.5 \\
\hline W7 & 8 Nov 2008 & 38.438 & -12.979 & 835 & 15.9 & 35.9 & 20 & 5.2 & 2.6 \\
\hline W9 & 9 Nov 2008 & 31.175 & -14.866 & 1463 & 17.2 & 36.4 & 10 & 0.60 & 0.19 \\
\hline W11 & 12 Nov 2008 & 25.196 & -17.858 & 1296 & 21.0 & 36.8 & 10 & 2.8 & 3.3 \\
\hline W13 & 14 Nov 2008 & 16.861 & -20.861 & 950 & 22.5 & 36.8 & 4.6 & 0.49 & 0.61 \\
\hline W15 & 17 Nov 2008 & 9.608 & -19.830 & 1041 & 28.6 & 35.2 & 1.4 & 0.42 & 1.3 \\
\hline W17 & 19 Nov 2008 & 4.109 & -15.606 & 925 & 29.1 & 34.6 & 1.6 & 0.09 & 0.18 \\
\hline Mean in $\mathrm{NH}$ & & & & & & & $17 \pm 14$ & $5.7 \pm 9.9$ & $2.3 \pm 2.8$ \\
\hline W19 & 21 Nov 2008 & -1.613 & -10.708 & 935 & 26.1 & 36.1 & 0.33 & 0.02 & 0.11 \\
\hline W21 & 23 Nov 2008 & -7.106 & -6.061 & 1000 & 25.5 & 36.2 & 0.35 & 0.03 & 0.31 \\
\hline W23 & 25 Nov 2008 & -13.414 & -0.651 & 1000 & 22.9 & 36.2 & 0.43 & 0.07 & 0.84 \\
\hline W25 & 29 Nov 2008 & -24.301 & 9.070 & 1000 & 19.1 & 35.5 & 0.91 & 0.21 & 0.61 \\
\hline W27 & 7 Dec 2008 & -37.836 & 13.198 & 311 & 22.3 & 35.5 & 0.70 & 0.30 & 0.23 \\
\hline W29 & 10 Dec 2008 & -52.941 & 10.836 & 804 & 4.6 & 33.9 & 5.0 & 0.15 & 0.16 \\
\hline W31 & 14 Dec 2008 & -67.275 & -1.949 & 771 & -1.6 & 34.0 & 2.5 & 0.17 & 0.14 \\
\hline Mean in $\mathrm{SH}$ & & & & & & & $1.5 \pm 1.7$ & $0.14 \pm 0.10$ & $0.34 \pm 0.28$ \\
\hline
\end{tabular}

selective ions of 255 and 71 for HCHs, 261 and 73 for d6$\mathrm{HCH}$ and 290 for ${ }^{13} \mathrm{C}-\mathrm{HCB}$.

\subsection{QA/QC}

Breakthrough of the target analytes of the sampling methods has been checked on board R/V Polarstern (Lakaschus et al., 2002), and further proved during this cruise. Three field blanks were run for each sample type while blank showed very low values which were $22,13,10 \mathrm{pg}$ in air sample and $12,7,43 \mathrm{pg}$ in water sample for $\alpha-, \gamma-$ and $\beta-\mathrm{HCH}$, respectively. Method detection limits (MDLs) were derived from mean blank values plus three times the standard deviation $(\sigma)$ (for compounds showing no blanks a peak area of 100 was adopted as background response). Atmospheric MDLs were $0.03 \mathrm{pg} \mathrm{m}^{-3}$ for $\alpha-\mathrm{HCH}, 0.01 \mathrm{pg} \mathrm{m}^{-3}$ for $\gamma-$ and $\beta-\mathrm{HCH}$, and seawater MDLs were $0.02,0.06$ and $0.01 \mathrm{pg} \mathrm{l}^{-1}$ for $\alpha-, \gamma$ and $\beta-\mathrm{HCH}$. Recoveries of internal standard $\mathrm{d} 6-\mathrm{HCH}$ were $81 \pm 23 \%$ for water samples and $89 \pm 35 \%$ for air samples, respectively.

\subsection{Air mass back trajectories}

Air mass origins along the cruise segments of the individual air samples were calculated using NOAA's HYSPLIT model. Air mass back trajectories were calculated in $6 \mathrm{~h}$ steps tracing back the air masses for 7 day using the sampling height as arrival height (Fig. 2).

\section{Results and discussion}

Individual concentrations of $\mathrm{HCHs}$ in air and seawater are given in Tables 1 and 2. For aqueous samples, only dissolved concentrations were considered, as concentrations of $\mathrm{HCHs}$ are below the method detection limits in all filter samples. It is shown in Table 3 for Comparison of $\mathrm{HCH}$ concentrations measured in the present study with previous data in seawater and air of the oceans and Polar Regions.

\subsection{HCHs in the atmosphere}

The spatial distribution of the sum of gaseous $\alpha-\gamma-$ and $\beta$ $\mathrm{HCH}\left(\Sigma \mathrm{HCHs}\right.$, Fig. 1a) ranged from 12 to $37 \mathrm{pg} \mathrm{m}^{-3}$ (mean: $27 \pm 11 \mathrm{pg} \mathrm{m}^{-3}$ ) in the Northern Hemisphere (NH), and from 1.5 to $4.0 \mathrm{pg} \mathrm{m}^{-3}$ (mean: $2.8 \pm 1.1 \mathrm{pg} \mathrm{m}^{-3}$ ) in the Southern Hemisphere (SH). Our results were comparable to those of global oceans (Wong et al., 2011; Wu et al., 2010; Lakaschus et al., 2002; Dickhut et al., 2005; Ding et al., 2007). The highest concentration was present in the coast near Western Europe and northwestern Africa $\left(37 \mathrm{pg} \mathrm{m}^{-3}\right)$ and the lowest concentration was observed in Southern Ocean $\left(1.5 \mathrm{pg} \mathrm{m}^{-3}\right)$. $\mathrm{HCH}$ concentrations decreased significantly $\left(R^{2}=0.555\right.$, 

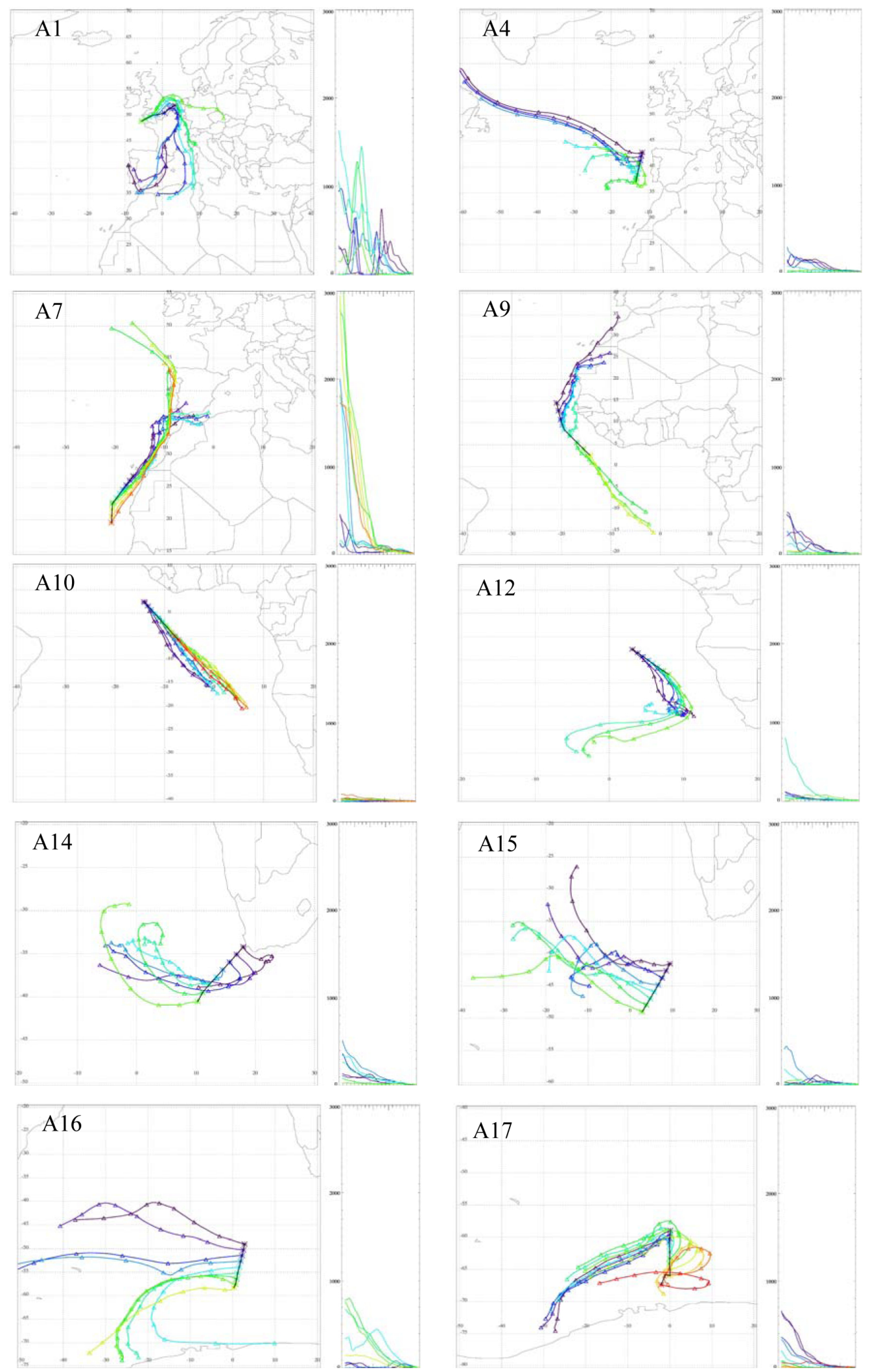

Fig. 2. $96 \mathrm{~h}$ air mass back trajectories (6h steps) and altitudinal profiles of the air mass parcels for the cruises ANT-XXV/1+2 (A1-A17). For samples longer than $72 \mathrm{~h}$, only every second BT was plotted. The black line indicates the cruise leg. 
Table 3. Comparison of $\mathrm{HCH}$ concentrations measured in the present study with previous data in seawater and air of the oceans and Polar Regions.

\begin{tabular}{|c|c|c|c|c|c|c|}
\hline Location & Year & $\alpha-\mathrm{HCH}$ & $\beta-\mathrm{HCH}$ & $\gamma-\mathrm{HCH}$ & $\alpha / \gamma-\mathrm{HCH}$ & reference \\
\hline \multicolumn{7}{|l|}{$\mathrm{HCHs}$ in air $\left(\mathrm{pg} \mathrm{m}^{-3}\right)$} \\
\hline North Pacific & 1989-1990 & $25-51$ & & $8.4-100$ & 4.0 & Iwata et al. (1993) \\
\hline Bering Sea & 1989-1990 & $230-390$ & & $21-67$ & 7.1 & Iwata et al. (1993) \\
\hline Chukchi Sea & 1989-1990 & $240-300$ & & $26-29$ & 9.6 & Iwata et al. (1993) \\
\hline Berling Sea & 1993 & $74-130$ & & $12-34$ & 4.6 & Jantunen et al. (1995) \\
\hline Alert $\left(82.5^{\circ}, 62.33^{\circ} \mathrm{W}\right)$ & 1993-1997 & $0.08-300$ & $0.02-3.8$ & $0.07-59$ & 6.5 & Hung et al. (2002) \\
\hline Canadian Archipelago & 1999 & $46 \pm 13$ & & $9.5 \pm 3.9$ & 4.8 & Jantunen et al. (2008) \\
\hline Arctic & 2003 & $2.1-11$ & & $0.2-2.1$ & 8.1 & Ding et al. (2007) \\
\hline North Pacific & 2003 & $6.5-19$ & & $1-4.6$ & 5.1 & Ding et al. (2007) \\
\hline North Pacific & 2008 & $26-56$ & $2-11$ & $10-36$ & 2.3 & Wu et al. (2010) \\
\hline Chuki and Beaufort Sea & 2008 & $18-28$ & $4.1-8.3$ & $5.8-19$ & 2.7 & Wu et al. (2010) \\
\hline Arctic & 2008 & $1.1-57$ & ND-7.8 & ND-16 & 3.9 & Wu et al. (2010) \\
\hline Arctic & $2007-2008$ & $7.5-48$ & & $2.1-7.7$ & & Wong et al. (2011) \\
\hline Alert $\left(82.5^{\circ}, 62.33^{\circ} \mathrm{W}\right)$ & $2002-2003$ & $6.1-16$ & & $1.3-2.8$ & 5.3 & Becker et al. (2008) \\
\hline Zeppelin $\left(78.97^{\circ} \mathrm{N}, 11.88^{\circ} \mathrm{E}\right)$ & 2004-2005 & $16-17$ & & $2.4-2.8$ & 6.3 & Becker et al. (2008) \\
\hline Barrow $\left(71.3^{\circ} \mathrm{N}, 170.6^{\circ} \mathrm{W}\right)$ & $2002-2003$ & $6-37$ & $0.041-0.8$ & $0.89-5.8$ & 7.0 & Su et al. (2006) \\
\hline Valkarkai $\left(70.08^{\circ} \mathrm{N}, 170.93^{\circ} \mathrm{E}\right)$ & 2002 & $60-75$ & $0.26-9.5$ & $4.6-16$ & 8.6 & Su et al. (2006) \\
\hline Northeast Atlantic and Arctic & 2004 & $1-7$ & & $<1-10$ & 2.8 & Lohmann et al. (2009) \\
\hline North Atlantic $\left(2^{\circ} \mathrm{N}-46^{\circ} \mathrm{N}\right)$ & 1990-1991 & $24-140$ & & $8.5-215$ & 2.5 & Schreitmueller and Ballschmiter (1995) \\
\hline South Atlantic $\left(9^{\circ} \mathrm{S}-50^{\circ} \mathrm{S}\right)$ & 1990-1991 & $1.8-16$ & & $1.5-29$ & 0.7 & Schreitmueller and Ballschmiter (1995) \\
\hline $\operatorname{Arctic}\left(75^{\circ} \mathrm{N}-80^{\circ} \mathrm{N}\right)$ & $1999-2000$ & $12-21$ & & $3-7$ & 3.8 & Lakaschus et al. (2002) \\
\hline North Sea $\left(54^{\circ} \mathrm{N}\right)$ & 1999, 2001 & $10-40$ & & $10-69$ & 0.8 & Lakaschus et al. (2002) \\
\hline Atlantic $\left(30^{\circ} \mathrm{N}-30^{\circ} \mathrm{S}\right)$ & 1999-2000 & $0.6-10$ & & $24-47$ & $<0.1$ & Lakaschus et al. (2002) \\
\hline Southern Ocean $\left(30.2^{\circ} \mathrm{S}-66.2^{\circ} \mathrm{S}\right)$ & 1999-2000 & $0.3-1.9$ & & $0.1-5.1$ & 1.1 & Lakaschus et al. (2002) \\
\hline Gondwana (Antarctic) & 1990 & 4 & & 3.8 & 1.0 & Bidleman et al. (1993) \\
\hline Signy $\left(60^{\circ} 43^{\prime} \mathrm{S}, 45^{\circ} 36^{\prime} \mathrm{W}\right)$ & 1994-1995 & $0.9-8.4$ & $1.5-6.9$ & $1.5-59$ & 0.13 & Kallenborn et al. (1998) \\
\hline Western Antarctic & $2001-2002$ & $<0.05-0.52$ & & $<0.02-3.0$ & 0.81 & Dickhut et al. (2005) \\
\hline North Atlantic $\left(8.5^{\circ} \mathrm{N}-50.1^{\circ} \mathrm{N}\right)$ & 2008 & $4.8-31$ & $0.01-1.5$ & $4.7-14$ & 2.5 & This work \\
\hline South Atlantic $\left(1.6^{\circ} \mathrm{S}-67.3^{\circ} \mathrm{S}\right)$ & 2008 & $0.6-3.0$ & $0.04-0.42$ & $0.5-2.0$ & 1.3 & This work \\
\hline \multicolumn{7}{|l|}{$\mathrm{HCHs}$ in seawater $\left(\mathrm{pg} \mathrm{l}^{-1}\right)$} \\
\hline Atlantic $\left(50^{\circ} \mathrm{N}-50^{\circ} \mathrm{S}\right)$ & $1990-1991$ & $6.7-70$ & & $21-75$ & 0.5 & Schreitmueller and Ballschmiter (1995) \\
\hline Arctic & 1993-1994 & $230-2700$ & & $170-700$ & 5.2 & Jantunen and Bidleman (1998) \\
\hline Atlantic $\left(51.1^{\circ} \mathrm{N}-29.3^{\circ} \mathrm{S}\right)$ & 1987 & $10-470$ & & $2.6-1240$ & 5.3 & Lakaschus et al. (2002) \\
\hline Atlantic $\left(50.6^{\circ} \mathrm{N}-30.8^{\circ} \mathrm{S}\right)$ & 1989 & $15-530$ & & $3.6-1970$ & 3.7 & Lakaschus et al. (2002) \\
\hline Atlantic $\left(53.9^{\circ} \mathrm{N}-63.4^{\circ} \mathrm{S}\right)$ & 1991 & $5.0-140$ & & $0.9-570$ & 4.5 & Lakaschus et al. (2002) \\
\hline Atlantic $\left(54.05^{\circ} \mathrm{N}-55.8^{\circ} \mathrm{S}\right)$ & 1993 & $6.1-110$ & & $0.7-560$ & 5.4 & Lakaschus et al. (2002) \\
\hline Atlantic $\left(52.75^{\circ} \mathrm{N}-63.66^{\circ} \mathrm{S}\right)$ & 1997 & $3.6-100$ & & $0.9-740$ & 3.7 & Lakaschus et al. (2002) \\
\hline Canadian Archipelago & 1999 & $1100-5400$ & $56-160$ & $190-450$ & 11.2 & Bildleman et al. (2007) \\
\hline North Atlantic and Arctic & 1999-2000 & $59-690$ & & $72-504$ & 1.8 & Lakaschus et al. (2002) \\
\hline North Sea $\left(54^{\circ} \mathrm{N}\right)$ & 1999, 2001 & 98 & & 330 & 0.3 & Lakaschus et al. (2002) \\
\hline Atlantic $\left(46.9^{\circ} \mathrm{N}-30^{\circ} \mathrm{S}\right)$ & $1999-2000$ & $2-69$ & & $1.4-130$ & 0.8 & Lakaschus et al. (2002) \\
\hline Southern Ocean $\left(30.2^{\circ} \mathrm{S}-66.2^{\circ} \mathrm{S}\right)$ & 1999-2000 & $2.9-9.6$ & & $0.7-5.5$ & 4.1 & Lakaschus et al. (2002) \\
\hline Western Antarctic & $2001-2002$ & $1.6-4.54$ & & $0.90-11$ & 1.6 & Dickhut et al. (2005) \\
\hline Northeast Atlantic and Arctic & 2004 & $1.1-65$ & & $0.4-21$ & 2.8 & Lohmann et al. (2009) \\
\hline Arctic & $2007-2008$ & $250-1300$ & & $55-340$ & 3.9 & Wong et al. (2011) \\
\hline North Atlantic $\left(8.5^{\circ} \mathrm{N}-50.1^{\circ} \mathrm{N}\right)$ & 2008 & $1.4-47$ & $0.18-9.5$ & $0.09-7.2$ & 7.3 & This work \\
\hline South Atlantic $\left(1.6^{\circ} \mathrm{S}-67.3^{\circ} \mathrm{S}\right)$ & 2008 & $0.33-5.0$ & $0.11-0.84$ & $0.02-0.30$ & 9.4 & This work \\
\hline
\end{tabular}

$P>0.001)$ from the North Atlantic to the Southern Ocean, reflecting the extensive utilization of $\mathrm{HCHs}$ in the $\mathrm{NH}$ in the 1980s.

In the $\mathrm{NH}$, average concentrations of $17 \pm 11 \mathrm{pg} \mathrm{m}^{-3}$ (range: $\quad 4.8-31 \mathrm{pg} \mathrm{m}^{-3}$ ), $9.0 \pm 4.0 \mathrm{pg} \mathrm{m}^{-3}$ (range $4.7-$ $\left.14 \mathrm{pg} \mathrm{m}^{-3}\right)$ and $0.40 \pm 0.75 \mathrm{pg} \mathrm{m}^{-3}\left(0.01-1.5 \mathrm{pg} \mathrm{m}^{-3}\right)$ were determined for $\alpha$-, $\gamma$ - and $\beta$-HCH. The gaseous concentrations of $\alpha-\mathrm{HCH}\left([\alpha-\mathrm{HCH}]_{\text {gas }}\right)$ in the $\mathrm{NH}$ were $\sim 2$ times higher than those $\left(4.1-12 \mathrm{pg} \mathrm{m}^{-3}\right)$ found in December 1999 (Lakaschus et al., 2002), and comparable to the Canadian Arctic during 2007-2008 (7.5-48 $\mathrm{pg} \mathrm{m}^{-3}$ ) (Wong et al., 2011), 2000-2003 (23 $\left.\pm 10 \mathrm{pg} \mathrm{m}^{-3}\right)$ (Su et al., 2006), and 
European Arctic in July $2000\left(17 \pm 4 \mathrm{pg} \mathrm{m}^{-3}\right.$ ) (Lakaschus et al., 2002). Varying $[\alpha-\mathrm{HCH}]_{\text {gas }}$ has been also observed in the northern Pacific Ocean in summer of 2003 $\left(9.9 \pm 8.3 \mathrm{pg} \mathrm{m}^{-3}\right)$ and $2008\left(33 \pm 16 \mathrm{pg} \mathrm{m}^{-3}\right)$, respectively. $[\gamma-\mathrm{HCH}]_{\text {gas }}\left(4.7-14 \mathrm{pg} \mathrm{m}^{3}\right)$ decreased in comparison to concentrations measured in December of $1999\left(0.1-45 \mathrm{pg} \mathrm{m}^{-3}\right)$ (Lakaschus et al., 2002) and were also lower than those values presented for the North Pacific in $2003\left(0.2-49 \mathrm{pg} \mathrm{m}^{-3}\right)$ (Ding et al., 2007), and comparable to those in the Arctic in 2008 (Wu et al., 2010; Ding et al., 2007). [ $\gamma-\mathrm{HCH}]_{\text {gas }}$ was slightly higher than concentrations reported from International Polar Year expeditions in the Canadian Arctic in $2008\left(2.1-7.7 \mathrm{pg} \mathrm{m}^{-3}\right.$ ) (Wong et al., 2011). Concentrations of $\beta$ - $\mathrm{HCH}$ were $1-2$ orders of magnitude lower than those measured in the North Pacific and adjacent Arctic (Wu et al., 2010 ), indicating geographic application of $\beta-\mathrm{HCH}$ in the world. Generally, the elevated concentrations of $\mathrm{HCHs}$ measured in air samples near the European and northwest African coast (A4, A7 and A9; Fig. 2) revealed volatilization of "old" $\mathrm{HCHs}$ from the continents or deep Ocean with past contamination along with undefined sources (Nizzetto et al., 2010; Jaward et al., 2004; Lohmann et al., 2009).

In the $\mathrm{SH}$, the means of $[\alpha-\mathrm{HCH}]_{\mathrm{gas}},[\gamma-\mathrm{HCH}]_{\mathrm{gas}}$ and $[\beta-\mathrm{HCH}]_{\text {gas }}$ were $1.6 \pm 0.84 \mathrm{pg} \mathrm{m}^{-3}, 1.1 \pm 0.52 \mathrm{pg} \mathrm{m}^{-3}$ and $0.14 \pm 0.14 \mathrm{pg} \mathrm{m}^{-3}$, respectively, which are $\sim 10-30 \%$ of those in the $\mathrm{NH}$, indicating slow interhemispheric mixing and lower previously usage in the Southern Hemisphere. From the Equator to Cape Town, $[\alpha-\mathrm{HCH}]_{\text {gas }}$ were similar to those measured in 1999 , whereas $[\gamma-\mathrm{HCH}]_{\text {gas }}$ decreased by factor of 10 , which likely results from the global reduction of lindane usage in the late 1990s (Lakaschus et al., 2002). From Cape Town $\left(32^{\circ} \mathrm{S}\right)$ to Neumayer Station (70.4 $4^{\circ}$ ) (A14-A17) concentrations of $\alpha-, \gamma-$ and $\beta$-HCH were relatively constant and comparable to those measured in 1999 (Lakaschus et al., 2002), and along the Western Antarctic peninsula (Dickhut et al., 2005), illustrating background levels of HCHs in the Southern Ocean.

\subsection{HCHs in seawater}

Dissolved $\alpha-, \beta$ - and $\gamma$-HCH concentrations in seawater displayed a wide range of concentrations from $50.9^{\circ} \mathrm{N}$ to $67.3^{\circ} \mathrm{S}$ (Fig. 1b). $[\alpha-\mathrm{HCH}]_{\text {diss }}$ ranged from 0.33 to $47 \mathrm{pgl}^{-1}$, with an average of $17 \pm 14 \mathrm{pgl}^{-1}$ in the $\mathrm{NH}$ and $1.5 \pm 1.7 \mathrm{pg}^{-1}$ in the $\mathrm{SH}$. $[\gamma-\mathrm{HCH}]_{\text {diss }}$ were generally lower than $[\alpha-\mathrm{HCH}]_{\text {diss }}$, ranging from 0.02 to $33 \mathrm{pg}^{-1}$ across Atlantic transect with an average of $5.7 \pm 9.9 \mathrm{pg}^{-1}$ in the $\mathrm{NH}$ and $0.14 \pm 0.10 \mathrm{pg}^{-1}$ in the SH. Except the sample $\mathrm{W} 1\left(50.923^{\circ} \mathrm{N}, 1.311^{\circ} \mathrm{E}\right)$ from the North Sea, $[\beta-$ $\mathrm{HCH}]_{\text {diss }}$ showed similar level as $\gamma-\mathrm{HCH}$ with a mean of $2.3 \pm 2.8 \mathrm{pgl}^{-1}$ in the $\mathrm{NH}$ and $0.34 \pm 0.28 \mathrm{pg} \mathrm{l}^{-1}$ in the $\mathrm{SH}$. The highest concentrations were observed in the North Sea for $\alpha$ - and $\gamma-\mathrm{HCH}$, while $\beta$-HCH dominated near the southern European coast. $\alpha$ - and $\gamma$-HCH also showed elevated concentrations in this area. In general, both $\alpha$ - and $\gamma-\mathrm{HCH}$ showed clearly increasing concentrations with increasing latitude north and south of the Equator, further illustrating the concept of cold trapping in high latitudes region and less interhemispheric mixing. Correlation analyses also revealed that $[\alpha-\mathrm{HCH}]_{\mathrm{diss}}\left(R^{2}=0.792, p>0.0005\right)$ and $[\gamma-\mathrm{HCH}]_{\mathrm{diss}}$ $\left(R^{2}=0.329,0.08\right)$ were significantly positively correlated to latitude in the $\mathrm{NH}$ and inversely correlated to $T_{\text {water }}(\alpha-\mathrm{HCH}$, $\left.R^{2}=0.650, P>0.003 ; \gamma-\mathrm{HCH}, R^{2}=0.150, P>0.15\right)$. Similar trends were observed in the $\mathrm{SH}$ as well, with positive correlation with latitudes $\left(\alpha-\mathrm{HCH}, R^{2}=0.470, P>0.05 ; \gamma\right.$ $\left.\mathrm{HCH}, R^{2}=0.254, P>0.14\right)$ and negative correlation with temperatures $T_{\text {water }}$ for $\alpha$-HCH $\left(R^{2}=0.609, P>0.02\right)$, respectively. However, no clear latitudinal and temperature trends were observed for $\beta$ - $\mathrm{HCH}\left(R^{2}=0.108-0.134\right)$.

\subsection{Temporal and latitudinal trends of HCHs in surface seawater}

Comparison of HCH in 1999/2000 with those obtained between 1987 and 1997 have been performed in Lakaschus et al. (2002), and exhibited a strong decline for $\alpha$-HCH between $50^{\circ} \mathrm{N}$ and $60^{\circ} \mathrm{S}$, and no clear trend for $\gamma-\mathrm{HCH}$. To evaluate updated temporal variation in the Atlantic, the new data set from this study and the historical data were merged into Figure $3 \mathrm{a}$ and $\mathrm{b}$ for a close comparison.

Similar latitudinal trends in the NH have been observed in all cruises from 1987 to 2008. Slightly increasing tendency from the Equator to the Southern Ocean also appeared in the SH. From $50^{\circ} \mathrm{N}$ to $30^{\circ} \mathrm{S}$, concentrations of $\alpha-\mathrm{HCH}$ in the present work were lower by factor of 10-50 than those measured in 1987-1997 and just slightly lower than those in 1999/2000. The concentrations of $\gamma$-HCH obviously decreased in comparison to those reported in 1987-2000, especially showed clearly declining trend from 2000-2008. The different trends for $\alpha$ - and $\gamma$-HCH suggest (i) the influence of international regulation on technical $\mathrm{HCHs}$ and lindane; and (ii) variable environmental behavior and fate for $\alpha$ - and $\gamma-\mathrm{HCH}$. There was a rather high variability presented in the tropic region for both $\alpha$ - and $\gamma$-HCH. Unlike explanation by Lakaschus et al. (2002) for $\gamma-\mathrm{HCH}$ in 1999, the high precipitation rate of approximately $2000 \mathrm{~mm} \mathrm{yr}^{-1}$ in the Intertropical Convergence Zone could cause significantly dilution rather than addition due to the intensive wet deposition. Another important factor is intensive biomass blooming in the tropical region, which has been observed during this cruise as well. The Equator tread winds bring massive Sahara dust containing nutrients and elements into the tropic ocean (Jullien et al., 2007; Cole et al., 2009; Pohl et al., 2011), which accelerates phytoplankton and zooplankton blooming in surface water of the Atlantic (Fernández et al., 2010; Guieu et al., 2010; Neogi et al., 2011; Taylor et al., 2011). The adsorption of $\alpha$ - and $\gamma-\mathrm{HCH}$ to biomass and particles and further removal by sedimentation and degradation may reduce the dissolved $\mathrm{HCHs}$ in the tropic region, which 


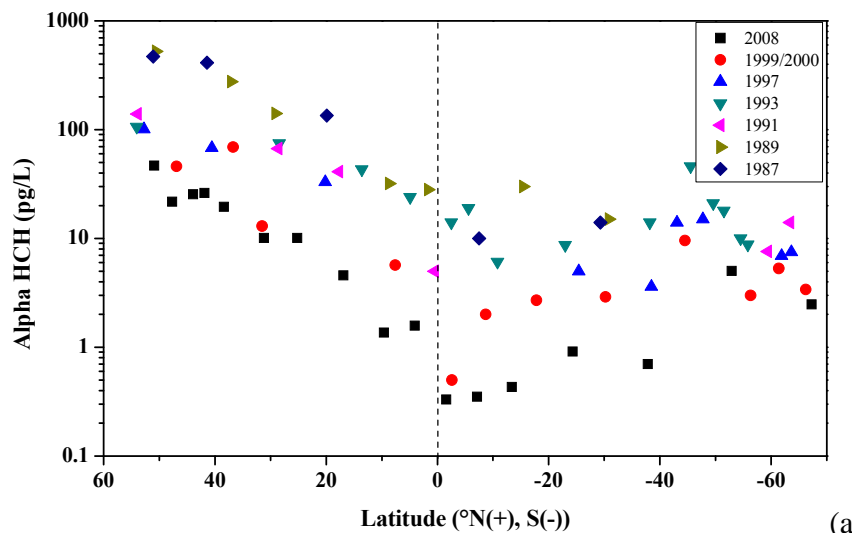

(a)

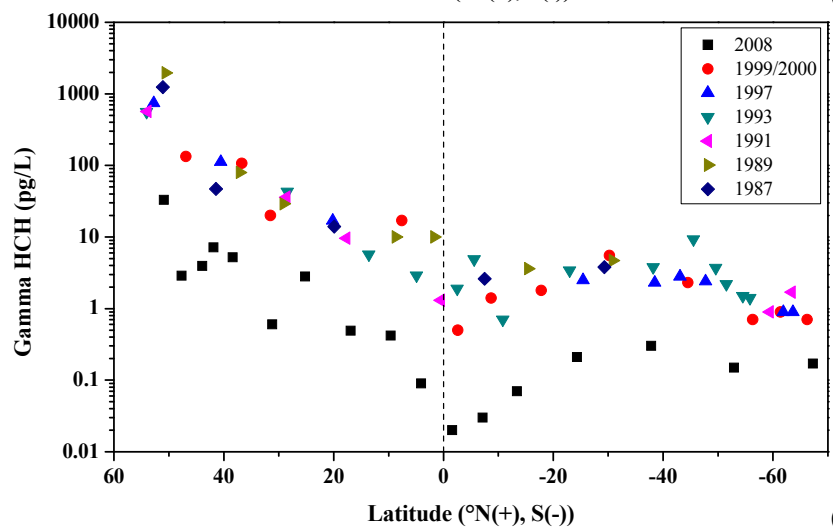

(b)

Fig. 3. Temporal and latitudinal distribution of $\alpha-\mathrm{HCH}$ (a) and $\gamma$ $\mathrm{HCH}(\mathbf{b})$ in the Atlantic and the Southern Ocean measured during cruise ANT-V (1987), ANT-VII (1989), ANT-X (1991), ANT-XI (1993), ANT-XV (1997), ANT-XVII (1999/2000) and ANT-XXV (2008, this work)

has been reported in a recent study for $\mathrm{HCHs}$ in mediterrancean seawater (Berrojalbiz et al., 2011).

The concentrations of $\alpha-\mathrm{HCH}$ in the Southern Ocean are quite variable, which can be addressed to the complex frontal system. It has been pointed out that elevated $[\alpha-\mathrm{HCH}]_{\text {diss }}$ was present between $40^{\circ} \mathrm{S}$ and $50^{\circ} \mathrm{S}$ from 1993 to 2000 (Lakaschus et al., 2002), this phenomenon was also found in this present study. The sampling data of W27, W29 and W31 showed a salinity decrease from 35.5 to 33.9 and 34.0 , and temperature decreased from $22.3{ }^{\circ} \mathrm{C}$ down to 4.6 and $-1.6^{\circ} \mathrm{C}$ as well. This is caused by an influx of fresh melting sea ice and snow water from the Antarctic shelf and results in a transfer the "old" contamination back to the Southern Ocean (Dickhut et al., 2005). Moreover, the Southern African current may transport HCHs from Indian Ocean to the Atlantic and moves them northward by the path of thermohaline circulation. This input may significantly contribute to the elevated $\mathrm{HCH}$ in the Southern Ocean.
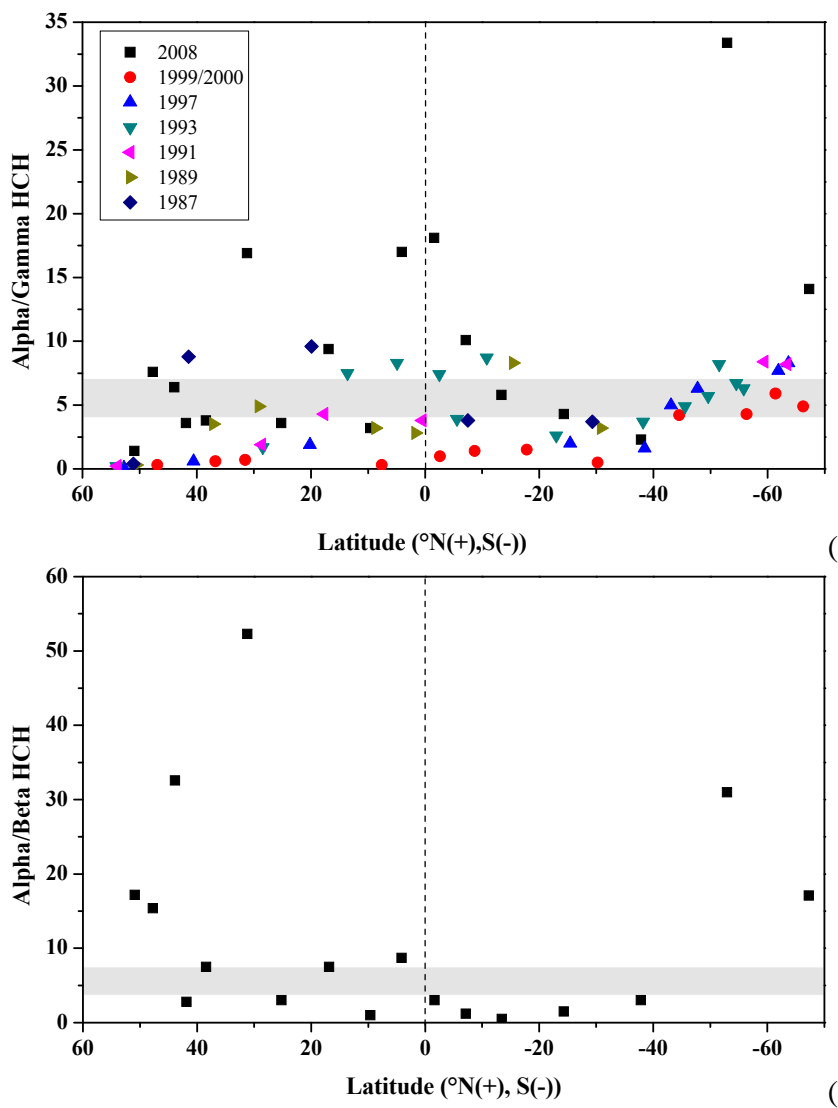

(a)

(b)

Fig. 4. Temporal and latitudinal variation of $\alpha-/ \gamma-\mathrm{HCH}$ ratio (a) in the Atlantic and the Southern Ocean measured during cruise ANT-V (1987), ANT-VII (1989), ANT-X (1991), ANT-XI (1993), ANT-XV (1997), ANT-XVII (1999/2000) and ANT-XXV (2008, this work), and the latitudinal variation of $\alpha-/ \beta-\mathrm{HCH}$ ratio (b) obtained in this work (2008). $\alpha-/ \gamma-\mathrm{HCH}$ and $\alpha-/ \beta-\mathrm{HCH}$ and ratios in technical mixtures are highlighted in gray.

\section{4 $\alpha / \gamma-\mathrm{HCH}$ and $\alpha / \beta-\mathrm{HCH}$ ratios in surface water}

Variations of $\alpha / \gamma-\mathrm{HCH}$ and $\alpha / \beta-\mathrm{HCH}$ ratios in space and time are highly influenced by the historical usage of technical $\mathrm{HCH}$ and lindane, and the environmental behaviors of different isomers. The most widely quoted composition of technical $\mathrm{HCH}$ is $60-70 \% \alpha / \gamma-\mathrm{HCH}, 5-12 \% \alpha / \gamma-\mathrm{HCH}$ and other isomers, resulting $\alpha / \gamma-\mathrm{HCH}$ and $\alpha / \beta-\mathrm{HCH}$ ratio about $4-7$ (Iwata et al., 1993). As show in Fig. 4, obviously high $\alpha / \gamma$ $\mathrm{HCH}$ values were present in 2008 in comparison to 1987 2000 , and mostly above the range of 5-7 of the $\alpha / \gamma-\mathrm{HCH}$ ratio in technical mixture (Iwata et al., 1993). In contrast to the present results, $\alpha / \gamma-\mathrm{HCH}$ ratios in the $\mathrm{NH}$ were mostly less than 4.5, and reached 0.1-2 in 1991 and 1999, indicating intensive application of lindane after a ban for technical $\gamma$ $\mathrm{HCH}$ during long range transport (Oehme et al., 1996). The highest $\alpha / \gamma-\mathrm{HCH}$ ratio 33 was found in the Southern Ocean; again indicates high persistence of $\alpha-\mathrm{HCH}$ in remote region. 
So far, $\alpha / \beta-\mathrm{HCH}$ ratios were only insufficiently studied. In this study, $\alpha / \beta-\mathrm{HCH}$ ratios varied from 0.5 to 52 , highlighted different environmental behavior of $\alpha$ - and $\beta$-HCH isomers. Generally, $\beta-\mathrm{HCH}$ is one of the five stable isomer of technical $\mathrm{HCH}$, and accounts for $5-14 \%$ of the technical formation. Unlike $\alpha$ - and $\gamma-\mathrm{HCH}, \beta-\mathrm{HCH}$ has a higher affinity to water than air, reflected in its lower Henry's law constant and higher water solubility. Low $\alpha / \beta-\mathrm{HCH}$ ratios $(<4)$ may suggest input sources of $\mathrm{HCHs}$ from adjacent landmasses. In the Southern Ocean as atmospheric transport and deposition is the major pathway, high $\alpha / \beta-\mathrm{HCH}$ ratios were present in this region (31 for $\mathrm{W} 27$ and 17 for $\mathrm{W} 31$ ).

\subsection{Air-water gas exchange}

The direction (or equilibrium status) of the gas exchange was estimated based on the fugacity ratio $f_{\mathrm{A}} / f_{\mathrm{W}}$, and the exchange fluxes were calculated using the two-film model which have been applied in Xie et al. (2011) and Lohmann et al. (2009). Briefly, the fugacity ratio was calculated using Eq. (1).

$\frac{f_{\mathrm{A}}}{f_{\mathrm{W}}}=\frac{C_{\mathrm{A}} R T_{\mathrm{A}}}{C_{\mathrm{W}} H}$

where $f_{\mathrm{W}}$ and $f_{\mathrm{A}}$ are the fugacities in water and air, $C_{\mathrm{W}}$ and $C_{\mathrm{A}}$ are the dissolved and gaseous concentrations in water and air $\left(\mathrm{pg} \mathrm{m}^{-1}\right), H$ is the Henry's Law constant $\left(\mathrm{Pa} \mathrm{m}^{-3} \mathrm{~mol}^{-1}\right)$ at the given water temperature and corrected by the salinity according to Schwarzenbach et al. (2003), $R$ is the gas constant $\left(8.31 \mathrm{~Pa} \mathrm{~m}^{-3} \mathrm{~K}^{-1} \mathrm{~mol}^{-1}\right)$ and $T_{\mathrm{A}}$ is the air temperature (K). The Henry's Law constant of $\mathrm{HCH}$ and its temperature dependence was taken from Sahsuvar et al. (2003) and Cetin and Odabasi (2005). Generally, a fugacity ratio $f_{\mathrm{A}} / f_{\mathrm{W}}=1$ means a system at equilibrium, whereas $f_{\mathrm{A}} / f_{\mathrm{W}}>1$ and $f_{\mathrm{A}} / f_{\mathrm{W}}<1$ indicates deposition and volatilization, respectively (Eq. 1). Due to uncertainties of knowing air-water transfer coefficient, a significant deviation from equilibrium cannot be assessed within a factor of 3 around a fugacity ratio of 1 (Bruhn et al., 2003; Lohmann et al., 2009).

The air-seawater gas exchange was calculated based on following Eq. (2) (Liss and Slater, 1974; Bidleman and McConnell, 1995; Schwarzenbach et al., 2003)

$F_{\mathrm{AW}}=K_{\mathrm{OL}}\left(C_{\mathrm{W}}-\frac{C_{\mathrm{A}}}{H^{\prime}}\right)$

where $H^{\prime}$ is the dimensionless temperature and salinity corrected Henry's Law constant defined as $H^{\prime}=H / R T(R=$ gas constant, $T=$ Temperature). $K_{\mathrm{OL}}\left(\mathrm{m} \mathrm{h}^{-1}\right)$ is the overall airwater mass transfer coefficient compromising the resistances to mass transfer in both water $\left(K_{\mathrm{W}}, \mathrm{mh}^{-1}\right)$ and air $\left(K_{\mathrm{A}}\right.$, $\mathrm{m} \mathrm{h}^{-1}$ ) and is defined by Schwarzenbach et al. (2003):

$$
\begin{aligned}
& \frac{1}{K_{\mathrm{OL}}}=\frac{1}{K_{\mathrm{W}}}+\frac{1}{K_{\mathrm{A}} H^{\prime}} \\
& k_{\mathrm{A}}=\left(0.2 U_{10}+0.3\right) \times\left(\frac{D_{i, \text { air }}}{D_{\mathrm{H}_{2} \mathrm{O}, \text { air }}}\right)^{0.61} \times 36
\end{aligned}
$$

$k_{\mathrm{W}}=\left(0.45 U_{10}^{1.64}\right) \times\left(\frac{S c_{i}}{S c_{\mathrm{CO}_{2}}}\right)^{-0.5} \times 0.01$

$D_{\text {air }}$ is the diffusity in air, $U_{10}$ is the wind speed at $10 \mathrm{~m}$ height above sea level $\left(\mathrm{m} \mathrm{s}^{-1}\right)$, and $S c$ is the water phase Schmidt number which was taken from Schwarzenbach et al. (2003) for $\mathrm{CO}_{2}$. $D_{\text {air }}$ was calculated using the method described in Fuller et al. (1966) and $S c$ was calculated using the method described in Hayduk and Laudi (1974). The uncertainty of the flux can be estimated by propagation of the uncertainties in $C_{\mathrm{W}}(23 \%), C_{\mathrm{A}}(35 \%), K_{\mathrm{OL}}(40 \%)$ and $H$ (20\%, Sahsuvar et al., 2003), which is $61 \%$.

$f_{\mathrm{A}} / f_{\mathrm{W}}$ of $\alpha-\mathrm{HCH}$ ranged from 0.8 to 27 with most values $>3$, indicated air to water deposition dominating airseawater gas exchange directions (Fig. 5), which might also be caused by important loss terms in the water mass e.g. setting and degradation. Two values ( 0.8 for $\mathrm{W} 1$ and 1.9 for W3) were within 0.3 to 3 , which showed a dynamic equilibrium reached near the western European coast $\left(51^{\circ} \mathrm{N}-\right.$ $\left.45^{\circ} \mathrm{N}\right)$. For the $\gamma$-isomer, $f_{\mathrm{A}} / f_{\mathrm{W}}$ indicated net deposition in all samples $\left(774>f_{\mathrm{A}} / f_{\mathrm{W}}>3.8, n=17\right)$. Although $\beta$ - $\mathrm{HCH}$ has relatively low levels in the atmosphere, because it's lower $H$ value, $f_{\mathrm{A}} / f_{\mathrm{W}}$ varied between equilibrium (volatilization) and net deposition.

Lakaschus et al. (2002) found that in the North Atlantic air-water exchange status of $\alpha-\mathrm{HCH}$ changed from net deposition in 1990 to equilibrium in 1999, and a new equilibrium was being established on a lower concentration level than 1990 (Lakaschus et al., 2002). Obviously, the results from this work showed that a new equilibrium has established for $\alpha-\mathrm{HCH}$ on a lower level than 1999, while equilibrium status in the Atlantic and the Southern Ocean from $45^{\circ} \mathrm{N}$ to $67^{\circ} \mathrm{S}$ has been broken up and changed to net deposition again. This variability was also observed in the north Atlantic and the Arctic Ocean (Harner et al., 1999; Lohmann et al., 2009). Gas exchange directions of $\alpha-\mathrm{HCH}$ between seawater and air reversed in the western Arctic from net deposition in the 1980s to net volatilization in the 1990 s with declined primary emissions (Bidleman et al., 1995; Jantunen and Bidleman, 1995; Jantunen et al., 2008). While air-water exchange direction for $\gamma-\mathrm{HCH}$ have been dominated by net deposition in most studies (Harner et al., 1999; Jantunen et al., 2008; Lohmann et al., 2009), with volatilization occasionally reported in the western Arctic.

The air-water deposition fluxes were quite high for $\alpha-\mathrm{HCH}$ with a median of $3800 \mathrm{pg} \mathrm{m}^{-2}$ day $^{-1}$ through the cruise (Fig. 5), except W1 for a volatilization of $820 \mathrm{pg} \mathrm{m}^{-2}$ day $^{-1}$. Elevated net deposition occurred in the European and northwest African coast ranging from 3800 to $11000 \mathrm{pg} \mathrm{m}^{-2}$ day $^{-1}$, and was just slightly lower than those measured in mid-Atlantic region in 2000/2001 (Gioia et al., 2005). In the $\mathrm{SH}$, net deposition of $\alpha-\mathrm{HCH}$ ranged from 570 to $4700 \mathrm{pg} \mathrm{m}^{-2}$ day $^{-1}$, which are $\sim 10$ times lower than those in the NH. Relatively constant levels in atmosphere and decreasing water concentrations of $\alpha-\mathrm{HCH}$ in recent 


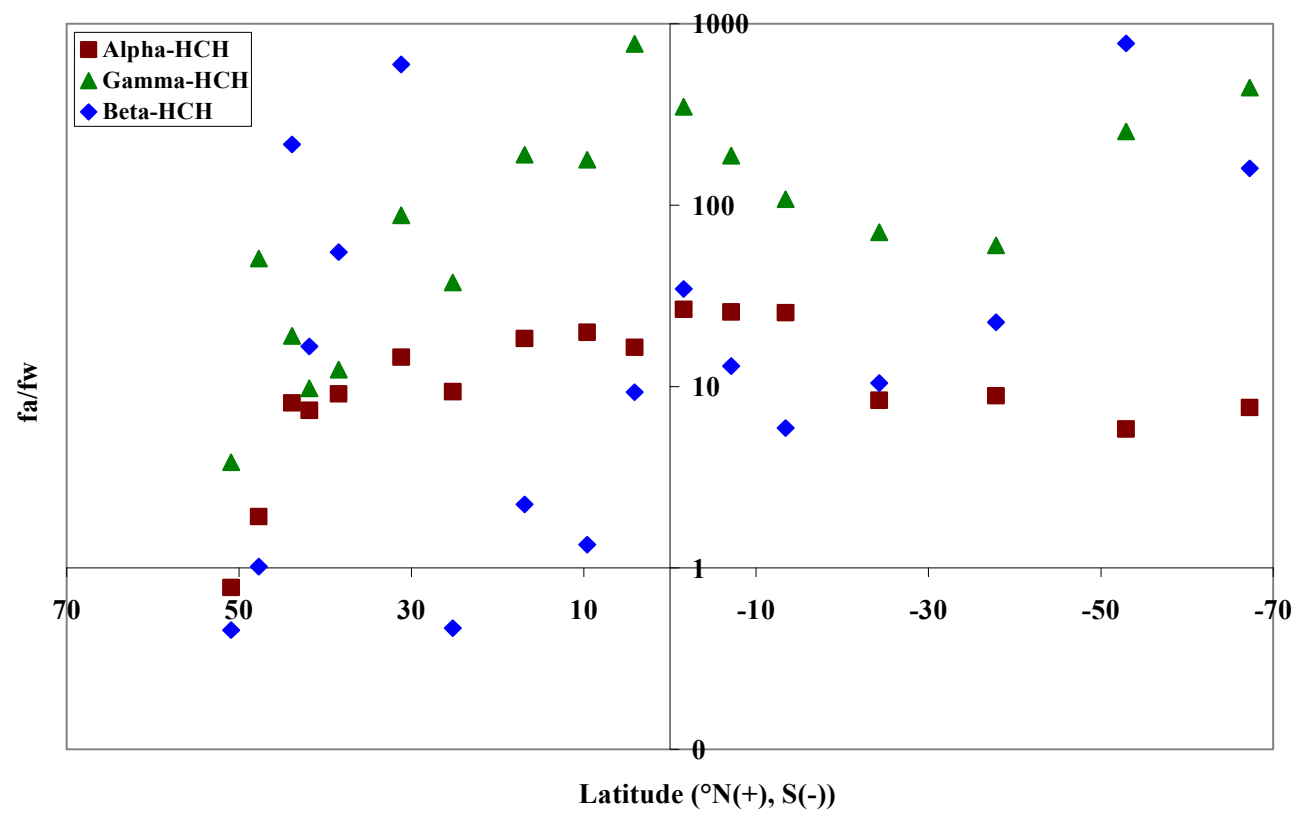

Fig. 5. Air-water fugacity ratio $\left(f_{\mathrm{A}} / f_{\mathrm{W}}\right)$ of $\alpha-, \gamma$ - and $\beta$-HCH in the Atlantic and Southern Ocean, a $f_{\mathrm{A}} / f_{\mathrm{W}}$ within the range $0.3-3$ means a system at equilibrium.

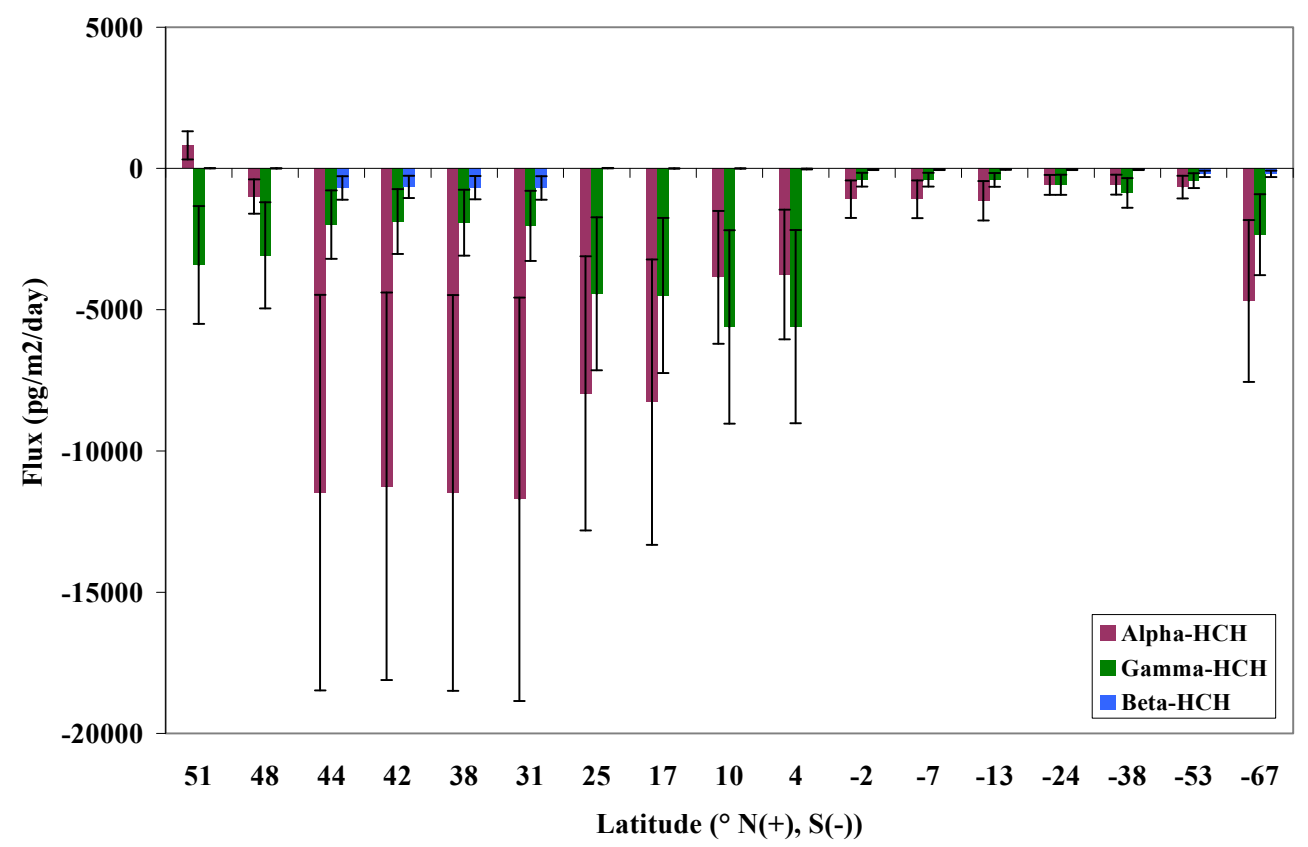

Fig. 6. Air-water gas exchange fluxes $\left(\mathrm{pg} \mathrm{m}^{-2} \mathrm{day}^{-1}\right.$ ) for $\alpha-, \gamma$ - and $\beta$-HCH in the Atlantic and Southern Ocean, negative value means net deposition, and positive value means volatilization.

years may contribute to the changing direction of the airseawater gas exchange and high deposition fluxes. A recent study in the Canadian Arctic (2007-2008) (Wong et al., 2011) showed net volatilization for $\alpha-\mathrm{HCH}$ with a mean of $6800 \pm 3200 \mathrm{pg} \mathrm{m}^{-2} \mathrm{day}^{-1}$, where the air concentrations were similar to this present work; but the water concentra- tions were 2-3 orders of magnitude higher than our results. Nevertheless, $\alpha-\mathrm{HCH}$ undergoes the iterative process of deposition and adsorption onto soil and vegetation, reemission into the atmosphere and re-deposition because of reduction in primary emissions and climate change. 
The $\gamma$-HCH was undergoing net deposition to surface waters with deposition fluxes ranging $400-5600 \mathrm{pg} \mathrm{m}^{-2}$ day $^{-1}$ (mean: $1987 \mathrm{pg} \mathrm{m}^{-2} \mathrm{day}^{-1}$ ) (Fig. 6), indicating continually loading into the Atlantic and the Southern Ocean since several decades. In comparison to the other two $\mathrm{HCH}$ species, $\beta-\mathrm{HCH}$ showed relatively low exchange fluxes (6$690 \mathrm{pg} \mathrm{m}^{-2} \mathrm{day}^{-1}$ for net deposition and $<12 \mathrm{pg} \mathrm{m}^{-2}$ day $^{-1}$ for net volatilization).

\section{Conclusions}

$\alpha-, \gamma-$, and $\beta-\mathrm{HCH}$ have been simultaneously measured in air and seawater of the Atlantic and the Southern Ocean in 2008. There was a marked difference between contaminant trends in atmosphere and surface waters highlighting the different time-scales affecting compounds in either compartment, reemission from the continental soil, vegetation and forest fire are considered sources for atmospheric $\mathrm{HCHs}$. Climate change may significantly accelerate the releasing process and drive long-range transport from sources to deposition in the open oceans. In the tropic ocean higher biological productivities may increase metabolism, sorption and settling fluxes and lead to lower concentrations of HCHs in the surface water, and thus control the air-water exchange process. Consequently, further investigation is necessary to elucidate the long term trends and the biogeochemistry process of $\mathrm{HCHs}$ in the oceanic environment.

Acknowledgements. We acknowledge the Alfred Wegener Institute for Polar and Marine Research (AWI), Bremerhaven, Germany, for the possibility of taking part in the expedition cruises. We are grateful to the crew of R/V Polarstern and the air chemistry team Annekatrin Dreyer and Armando Caba for their assistance on sampling. We thank Volker Matthias for help with the BTs.

Edited by: G. Herndl

\section{References}

Becker, S., Halsall, C. J., Tych, W., Kallenborn, R., Su, Y., and Hung, H.: Long-term trends in atmospheric concentrations of alpha- and gamma-HCH in the Arctic provide insight into the effects of legislation and climatic fluctuations on contaminant levels, Atmos. Environ, 42, 8225-8233, 2008.

Berrojalbiz, N., Dachs, J., Del Vento, S., Ojeda, M., Valle, M., Castro-Jiménez, J., Mariani, G., Wollgast, J., and Hanke, G.: Persistent Organic Pollutants in Mediterranean Seawater and Processes Affecting Their Accumulation in Plankton, Environ. Sci. Technol., 45, 4315-4322, 2011.

Bidleman, T. F. and McConnell, L. L.: A review of field experiments to determine air-water gas exchange of persistent organic pollutants, Sci. Total Environ., 159, 101-117, 1995.

Bidleman, T. F., Cotham, W. E., Addison, R. F., and Zinck, M. E.: Organic contamination in the Northwest Atlantic atmosphere at Sable Island, Nova-Scotia, 1988-89, Chemosphere, 24, 13891412, 1992.
Bidleman, T. F., Walla, M. D., Roura, R., Carr, E., and Schmidt, S.: Organochlorine pesticides in the atmosphere of the Southern Ocean and Antarctica, January-March, 1990, Mar. Pollut. Bull., 26, 258-262, 1993.

Bidleman, T. F., Jantunen, L. M., Falconer, R. L., Barrie, L. A., and Fellin, P.: Decline of hexachlorocyclohexane in the Arctic atmosphere and reversal of air-sea gas-exchange, Geophys. Res. Lett., 22, 219-222, 1995.

Bidleman, T. F., Kylin, H., Jantunen, L. M., Helm, P. A., and Macdonald, R. W.: Hexachlorocyclohexanes in the Canadian Archipelago. 1. Spatial Distribution and Pathways of $\alpha-, \beta$-, and $\gamma$-HCHs in Surface Water, Environ. Sci. Technol., 41, 26882695, 2007.

Breivik, K., Pacyna, J. M., and Münch, J.: Use of [alpha]-, [beta]- and [gamma]-hexachlorocyclohexane in Europe, 19701996, Sci. Total Environ., 239, 151-163, 1999.

Brown, T. N. and Wania, F.: Screening Chemicals for the Potential to be Persistent Organic Pollutants: A Case Study of Arctic Contaminants, Environ. Sci. Technol., 42, 5202-5209, 2008.

Bruhn, R., Lakaschus, S., and McLachlan, M. S.: Air/sea gas exchange of PCBs in the southern Baltic Sea, Atmos. Environ., 37, 3445-3454, 2003.

Cetin, B. and Odabasi, M.: Measurement of Henry's law constants of seven polybrominated diphenyl ether (PBDE) congeners as a function of temperature, Atmos. Environ., 39, 5273-5280, 2005.

Cole, J. M., Goldstein, S. L., deMenocal, P. B., Hemming, S. R., and Grousset, F. E.: Contrasting compositions of Saharan dust in the eastern Atlantic Ocean during the last deglaciation and African Humid Period, Earth Planet. Sc. Lett., 278, 257-266, 2009.

Dachs, J., Lohmann, R., Ockenden, W. A., Mejanelle, L., Eisenreich, S. J., and Jones, K. C.: Oceanic biogeochemical controls on global dynamics of persistent organic pollutants, Environ. Sci Technol., 36, 4229-4237, 2002.

Dickhut, R. M., Cincinelli, A., Cochran, M., and Ducklow, H. W.: Atmospheric concentrations and air-water flux of organochlorine pesticides along the western Antarctic Peninsula, Environ. Sci. Technol., 39, 465-470, 2005.

Ding, X., Wang, X. M., Xie, Z. Q., Xiang, C. H., Mai, B. X., Sun, L. G., Zheng, M., Sheng, G. Y., and Fu, J. M.: Atmospheric hexachlorocyclohexanes in the North Pacific Ocean and the adjacent Arctic region: Spatial patterns, chiral signatures, and sea-air exchanges, Environ. Sci. Technol., 41, 5204-5209, 2007.

Fenner, K., Scheringer, M., and Hungerbühler, K.: Prediction of overall persistence and long-range transport potential with multimedia fate models: robustness and sensitivity of results, Environ. Pollut., 128, 189-204, 2004.

Fernández, A., Mouriño-Carballido, B., Bode, A., Varela, M., and Marañón, E.: Latitudinal distribution of Trichodesmium spp. and N2 fixation in the Atlantic Ocean, Biogeosciences, 7, 3167 3176, doi:10.5194/bg-7-3167-2010, 2010.

Fuller, E. N., Schettler, P. D., and Giddings, J. C.: New method for prediction of binary gas-phase diffuesion coefficients, Industry and Engineering Chemistry, 58, 18-27, 1966.

Gioia, R., Offenberg, J. H., Gigliotti, C. L., Totten, L. A., Du, S. Y., and Eisenreich, S. J.: Atmospheric concentrations and deposition of organochlorine pesticides in the US Mid-Atlantic region, Atmos. Environ., 39, 2309-2322, 2005.

Guieu, C., Dulac, F., Desboeufs, K., Wagener, T., Pulido-Villena, E., Grisoni, J.-M., Louis, F., Ridame, C., Blain, S., Brunet, 
C., Bon Nguyen, E., Tran, S., Labiadh, M., and Dominici, J.M.: Large clean mesocosms and simulated dust deposition: a new methodology to investigate responses of marine oligotrophic ecosystems to atmospheric inputs, Biogeosciences, 7, 27652784, doi:10.5194/bg-7-2765-2010, 2010.

Harner, T., Kylin, H., Bidleman, T. F., Strachan, W. M. J.: Removal of alpha- and gamma-hexachlorocyclohexane and enantiomers of alpha-hexachlorocyclohexane in the eastern Arctic Ocean, Environ. Sci. Technol., 33, 1157-1164, 1999.

Hayduk, W. and Laudie, H.: Prediction of diffusion coefficients for nonelectrolytes in dilute aqueous solutions, AIChE Journal, 20, 611-615, 1974.

Hung, H., Halsall, C. J., Blanchard, P., Li, H. H., Fellin, P., Stern, G., and Rosenberg, B.: Temporal trends of organochlorine pesticides in the Canadian Arctic atmosphere, Environ. Sci. Technol., 36, 862-868. 2002.

Iwata, H., Tanabe, S., Sakal, N., and Tatsukawa, R.: Distribution of persistent organochlorines in the oceanic air and surface seawater and the role of ocean on their global transport and fate, Environ. Sci. Technol., 27, 1080-1098, 1993.

Jantunen, L. M. and Bidleman, T. F.: Reversal of the air-water gasexchange direction of hexachlorocyclohexanes in the Bering and Chukchi seas - 1993 versus 1988, Environ. Sci. Technol., 29, 1081-1089, 1995.

Jantunen, L. M. M. and Bidleman, T. F.: Organochlorine pesticides and enantiomers of chiral pesticides in Arctic Ocean water, Arch. Environ. Con. Tox., 35, 218-228, 1998.

Jantunen, L. M., Kylin, H., and Bidleman, T. F.: Air-water gas exchange of alpha-hexachlorocyclohexane enantiomers in the South Atlantic Ocean and Antarctica, Deep-Sea Res. Pt. II, 51, 2661-2672, 2004.

Jantunen, L. M., Helm, P. A., Kylin, H., and Bidlemant, T. F.: Hexachlorocyclohexanes (HCHs) in the Canadian archipelago. 2. Air-water gas exchange of alpha- and gamma-HCH, Environ. Sci. Technol., 42, 465-470, 2008.

Jaward, F. M., Barber, J. L., Booij, K., Dachs, J., Lohmann, R., and Jones, K. C.: Evidence for dynamic air-water coupling and cycling of persistent organic pollutants over the open Atlantic Ocean, Environ. Sci. Technol., 38, 2617-2625, 2004.

Jullien, E., Grousset, F., Malaizé, B., Duprat, J., Sanchez-Goni, M. F., Eynaud, F., Charlier, K., Schneider, R., Bory, A., Bout, V., and Flores, J. A.: Low-latitude "dusty events" vs. high-latitude “icy Heinrich events”, Quaternary Res., 68, 379-386, 2007.

Kallenborn, R., Oehme, M., Wynn-Williams, D. D., Schlabach, M., and Harris, J.: Ambient air levels and atmospheric long-range transport of persistent organochlorines to Signy Island, Antarctica, Sci. Total Environ., 220, 167-180, 1998.

Lakaschus, S., Weber, K., Wania, F., Bruhn, R., and Schrems, O.: The air-sea equilibrium and time trend of hexachlorocyclohexanes in the Atlantic Ocean between the Arctic and Antarctica, Environ. Sci. Technol., 36, 138-145, 2002.

Li, Y. F. and Macdonald, R. W.: Sources and pathways of selected organochlorine pesticides to the Arctic and the effect of pathway divergence on $\mathrm{HCH}$ trends in biota: a review, Sci. Total Environ., 342, 87-106, 2005.

Liss, P. S. and Slater, P. G.: 1 Flux of gases across air-sea interface, Nature, 247, 181-184, 1974.

Lohmann, R., Jurado, E., Pilson, M. E. Q., and Dachs, J.: Oceanic deep water formation as a sink of persistent organic pollutants,
Geophys. Res. Lett., 33, L12607, doi:10.1029/2006GL025953, 2006.

Lohmann, R., Breivik, K., Dachs, J., and Muir, D.: Global fate of POPs: Current and future research directions, Environ. Pollut., 150, 150-165, 2007.

Lohmann, R., Gioia, R., Jones, K. C., Nizzetto, L., Temme, C., Xie, Z., Schulz-Bull, D., Hand, I., Morgan, E., and Jantunen, L.: Organochlorine Pesticides and PAHs in the Surface Water and Atmosphere of the North Atlantic and Arctic Ocean, Environ. Sci. Technol., 43, 5633-5639, 2009.

Nizzetto, L., Lohmann, R., Gioia, R., Dachs, J., and Jones, K. C.: Atlantic Ocean Surface Waters Buffer Declining Atmospheric Concentrations of Persistent Organic Pollutants, Environ. Sci. Technol., 44, 6978-6984, 2010.

Neogi, S. B., Koch, B. P., Schmitt-Kopplin, P., Pohl, C., Kattner, G., Yamasaki, S., and Lara, R. J.: Biogeochemical controls on the bacterial population in the eastern Atlantic Ocean, Biogeosciences Discuss., 8, 7791-7821, doi:10.5194/bgd-8-7791-2011, 2011.

Oehme, M., Haugen, J. E., and Schlabach, M.: Seasonal changes and relations between levels of organochlorines in arctic ambient air: First results of an all-year-round monitoring program at $\mathrm{Ny}$ Alesund, Svalbard, Norway, Environ. Sci. Technol., 30, 22942304, 1996.

Pohl, C., Hennings, U., Croot, P., Daberkow, T., Budeus, G., and Rutgers v.d. Loeff, M.: Synoptic transects on the distribution of trace elements $(\mathrm{Hg}, \mathrm{Pb}, \mathrm{Cd}, \mathrm{Cu}, \mathrm{Ni}, \mathrm{Zn}, \mathrm{Co}, \mathrm{Mn}, \mathrm{Fe}, \mathrm{Al})$ in surface waters of the Northern- and Southern East-Atlantic, J. Marine Syst., 84, 28-41, 2011.

Sahsuvar, L., Helm, P. A., Jantunen, L. M., and Bidleman, T. F.: Henry's law constants for alpha-, beta-, and gammahexachlorocyclohexanes ( $\mathrm{HCHs}$ ) as a function of temperature and revised estimates of gas exchange in Arctic regions, Atmos. Environ., 37, 983-992, 2003.

Schreitmuller, J. and Ballschmiter, K.: Air-water equilibrium of hexachlorocyclohexanes and chloromethoxybenzenes in the north and south-Atlantic, Environ. Sci. Technol., 29, 207-215, 1995.

Schwarzenbach, R. P., Gschwend, P. M., and Imboden, D. M.: Environmental Organic Chemistry, John Wiley and Sons, New Jersey, 2003.

Shen, L., Wania, F., Lei, Y. D., Teixeira, C., Muir, D. C. G., and Bidleman, T. F.: Hexachlorocyclohexanes in the north American atmosphere, Environ. Sci. Technol., 38, 965-975, 2004.

Su, Y., Hung, H., Blanchard, P., Patton, G. W., Kallenborn, R., Konoplev, A., Fellin, P., Li, H., Geen, C., Stern, G., Rosenberg, B., and Barrie, L. A.: Spatial and seasonal variations of hexachlorocyclohexanes (HCHs) and hexachlorobenzene (HCB) in the Arctic atmosphere, Environ. Sci. Technol., 40, 6601-6607, 2006.

Taylor, B. B., Torrecilla, E., Bernhardt, A., Röttger, R., Piera, J., Peeken, I., and Bracher, A.: Characterization of phytoplankton communities by optical properties in the eastern Atlantic Ocean, Biogeosciences, in preparation, 2011.

Weber, J., Halsall, C. J., Muir, D. C. G., Teixeira, C., Burniston, D. A., Strachan, W. M. J., Hung, H., Mackay, N., Arnold, D., and Kylin, H.: Endosulfan and gamma-HCH in the Arctic: An assessment of surface seawater concentrations and air-sea exchange, Environ. Sci. Technol., 40, 7570-7576, 2006. 
Wong, F., Jantunen, L. M., Pucko, M., Papakyriakou, T., Staebler, R. M., Stern, G. A., and Bidleman, T. F.: Air-Water Exchange of Anthropogenic and Natural Organohalogens on International Polar Year (IPY) Expeditions in the Canadian Arctic, Environ. Sci. Technol., 45, 876-881, 2011.

Wu, X. G., Lam, J. C. W., Xia, C. H., Kang, H., Sun, L. G., Xie, Z. Q., and Lam, P. K. S.: Atmospheric HCH Concentrations over the Marine Boundary Layer from Shanghai, China to the Arctic Ocean: Role of Human Activity and Climate Change, Environ. Sci. Technol., 44, 8422-8428, 2010.
Xie, Z., Moller, A., Ahrens, L., Sturm, R., and Ebinghaus, R.: Brominated Flame Retardants in Seawater and Atmosphere of the Atlantic and the Southern Ocean, Environ. Sci. Technol., 45, 1820-1826, 2011. 